\title{
Kako uspešno opravimo vsak izpit
} Brian Duncalf

A

Skozi dvanajst poglavij seznani bralca s tehnikami učinkovitega učenja, $s$ tem, kako se spopasti s strahom pred preverjanjem znanja, kako si organizirati čas med opravljanjem izpita pri reševanju nalog in navsezadnje tudi s tem, kako si okrepiti samozavest in odpraviti živčnost pred izpitom. Knjiga je tudi pestro strukturirana in razgibana ter pregledna, tako da bralec z lahkoto osvaja poglavja (poglavja avtor začenja $\mathrm{z}$ reki ali obče veljavnimi modrostmi in jih zaokroži s povzetki).

Med drugim trdi, da je skrivnost uspešnega opravljanja izpitov v pripravah kandidata nanj. Kajti tudi pri slabih načinih učenja lahko žrtvujemo veliko časa in trdega dela, vendar pri izpitu kljub temu ne bomo uspešni. In izpiti niso sami sebi namen. Izobrazba, ki jo pridobimo z izpiti, nam veliko pove tudi o tem, kako se je človek sposoben spopadati s težavami, ki jih prinaša življenje. Avtor ne zanika tudi dejstva, da je študij ob delu neprimerno zahtevnejši od rednega študija, toda $\mathrm{z}$ rabo tehnik, ki jih navaja, je lažje premagati tudi te ovire.

Naslov knjige - Kako uspešno opravimo vsak izpit - lahko zahtevnejšega bralca morda odvrne $\mathrm{v}$ prepričanju, da knjiga prinaša

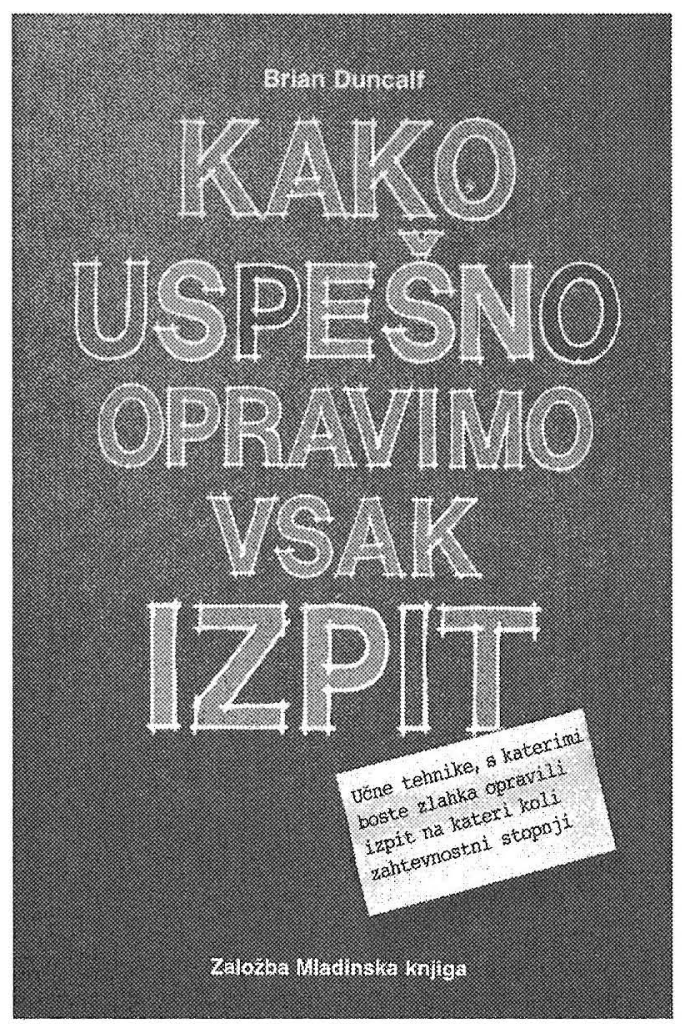

lahkotne recepte v » ameriškem « slogu, toda ni tako. Vsebina prinaša koristne nasvete za vsakogar, ki se še izobražuje, najsi gre za redno šolajoče se ali vse tiste, ki si znanje poglabljajo ob rednih vsakdanjih službenih dolžnostih. $\mathrm{Z}$ izpiti in podobnimi preizkusi znanja se $\mathrm{v}$ sodobnem svetu ljudje pogosto srečujejo in avtor nas dovolj razumljivo ter obenem tudi dovolj poglobljeno seznani s tem, kako se ob takih življenjskih situacijah bolje odrezati, predvsem pa tudi, kako se bolje nanje pripraviti.

Tanja Sulak 